\title{
First record of the Pacific oyster Magallana gigas (Thunberg, 1793) in the Baltic Sea proper
}

\author{
Christine Ewers-Saucedo* (D), Nele Heuer, Zoe Moesges, Kira Ovenbeck, Nicole Schröter and Dirk Brandis
}

\begin{abstract}
Since its introduction in the 1960's for aquaculture, the Pacific oyster Magallana gigas (Thunberg, 1793) has successfully spread along almost all European coasts with far-reaching consequences for marine ecosystems. Up to now, it has not been recorded from the Baltic Sea proper. This was considered a consequence of the low salinity conditions, which are not suitable for larval development. Here we report our first records of Pacific oysters in the German Baltic Sea, specifically in the Kiel Bight. We confirmed their species identification by genetic barcoding. We suggest that Pacific oysters were able to settle in the Baltic Sea proper due to unusually high salinities that prevailed since the summer of 2018. Should these conditions occur more frequently in the future, or M. gigas be able to adapt to lower salinities, oysters may become established in the Baltic Sea proper.
\end{abstract}

Keywords: Oyster, Magallana gigas, Baltic Sea, Salinity anomaly, Invasive species, Adaptation

\section{Introduction}

The Pacific oyster Magallana gigas (Thunberg, 1793), formerly Crassostrea gigas, is an established nonindigenous species along all European coasts with the exception of the Baltic Sea proper (Diederich et al. 2005; Cardoso et al. 2007; Wrange et al. 2010). The rapid spread of M. gigas throughout Europe was fueled by large-scale imports of spat oysters for aquaculture from Japan, where M. gigas is native, and British Columbia. The first successful aquacultures were established in Great Britain, Ireland, France and the Netherlands in the 1960s. As early as the 1970s, natural spat fall occurred for the first time (Wolff and Reise 2002; Smaal et al. 2009; Fey et al. 2010). In the German Wadden Sea, commercial farming of the Pacific oyster began in 1986, and in 1991 the first wild oysters were found outside the culture plot (Reise 1998). Since the 2000s, M. gigas has been distributed throughout the entire Wadden Sea (Reise et al. 2005; Nehring et al. 2009), and continues to

\footnotetext{
* Correspondence: ewers-saucedo@zoolmuseum.uni-kiel.de

Zoological Museum of the Christian-Albrechts University, Hegewischstrasse 3, 24105 Kiel, Germany
}

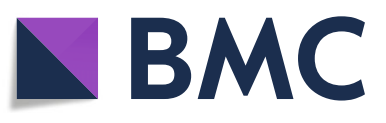

(C) The Author(s). 2020 Open Access This article is licensed under a Creative Commons Attribution 4.0 International License, which permits use, sharing, adaptation, distribution and reproduction in any medium or format, as long as you give

appropriate credit to the original author(s) and the source, provide a link to the Creative Commons licence, and indicate if changes were made. The images or other third party material in this article are included in the article's Creative Commons licence, unless indicated otherwise in a credit line to the material. If material is not included in the article's Creative Commons licence and your intended use is not permitted by statutory regulation or exceeds the permitted use, you will need to obtain permission directly from the copyright holder. To view a copy of this licence, visit http://creativecommons.org/licenses/by/4.0/. even Norway (Wrange et al. 2010) (Fig. 1a). Its easternmost confirmed occurrence to date is Isefjorden in the Belt Sea, while non-peer reviewed observations of $M$. gigas from Lolland, Seeland and the Kiel Bight exist (Dolmer et al. 2014; Bock and Lieberum 2019). In an extensive survey of the Scandinavian coast, oysters were generally absent where the salinity was below 20 PSU (Wrange et al. 2010). These conditions match the environmental limits of $M$. gigas larvae, the life history stage most sensitive to environmental deviations (Troost 2010). The larvae require salinities between 19 and 35 PSU for successful development, and temperatures between 18 and $35^{\circ} \mathrm{C}$ (Rico-Villa et al. 2009). The salinity in the western Baltic Sea ranged between 15 and 19 PSU in the past decades, with the lower salinities prevalent in the summertime (Lennartz et al. 2014). These conditions should be prohibitive for the colonization by the Pacific oyster. Nonetheless, here we report the first natural settlement of the Pacific oyster Magallana gigas in the Baltic Sea proper, specifically in the German Kiel Bight. We discuss how changing climate and hydrography may 


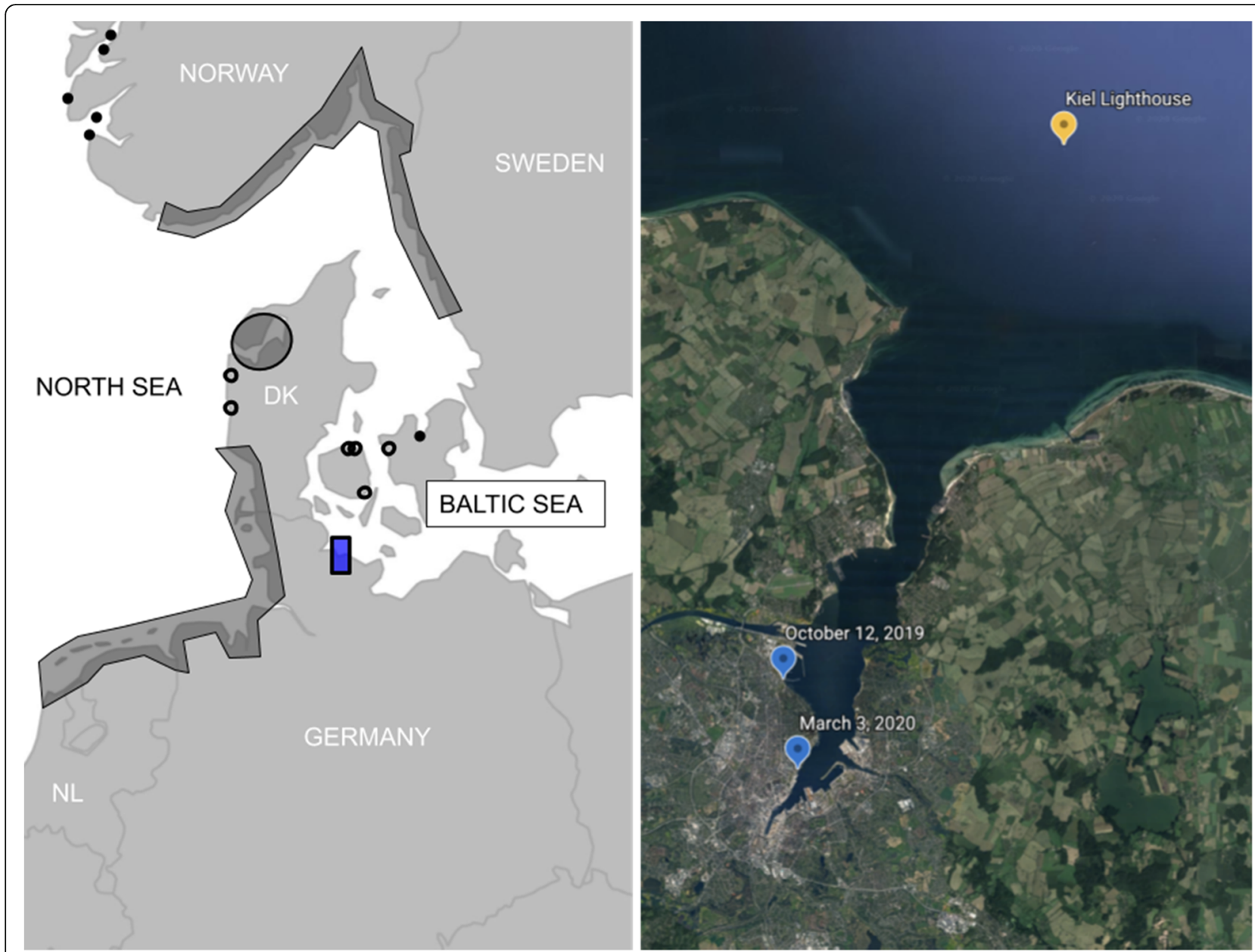

Fig. 1 a Overview of the known distribution of Magallana gigas in northern Europe and location of Kiel Bight (blue square). Previously published locations of M. gigas until 2008 are indicated by grey areas and black dots, which represent abundant and isolated oyster finds, respectively (Wrange et al. 2010). Additional locations of the government report of Dolmer et al. (2014) from ca. 2012 are denoted by black open circles. $\mathbf{b}$ Map of the Kiel Bight with sampling locations as blue pins, and the location of the hydrographic station 'Kiel Lighthouse' as a yellow pin, generated in Google Earth

have facilitated the eastward expansion of $M$. gigas into the Baltic Sea proper, and how likely the establishment of reproducing populations of Pacific oysters in the western Baltic Sea is.

\section{Specimens collection}

The first live oyster was observed during a beach survey at the 'Tirpitzmole' $\left(54.353036^{\circ} \mathrm{N}, 10.141309^{\circ} \mathrm{E}\right)$ on October 12, 2019, attached to a large metal pipe (Fig. 1b, Fig. 2a). At the time of discovery, strong winds had pushed the surface waters offshore and exposed parts of the sea bottom, including the pipe, which is normally covered by approximately $30 \mathrm{~cm}$ of water. The tidal influence at this part of the Baltic Sea is negligible. This oyster was removed on November 12, 2019 with a knife as a voucher specimen for the Zoological Museum of the Kiel University (catalogue number ZMK Mo10400). The oyster had a round shape and sculptured valves
(Fig. 2b, c). The maximal length of its left valve was 55.8 $\mathrm{mm}$. It was covered by the most abundant barnacle in the Baltic Sea, the bay barnacle Amphibalanus improvisus, green and brown algae. On March 2, 2020, six additional live oysters were collected at about $1 \mathrm{~m}$ water depth along the quay walls and footbridge poles of a marina in the innermost part of Kiel Fjord, SchleswigHolstein, Germany $\left(54.328458^{\circ} \mathrm{N}, 10.148032^{\circ} \mathrm{E}\right)$ (Fig. 1b) and deposited at the Zoological Museum of the Kiel University (catalogue numbers ZMK Mo10401Mo10406). These oysters had a smooth surface, and were attached to blue mussels (Mytilus edulis x trossulus hybrids) (Fig. 2d, e). They did not appear to smother the mussels, but rather overgrow one of their shells (Fig. 2d, e). The maximal lengths of their left valves were $33.2 \mathrm{~mm}$, $40.8 \mathrm{~mm}, 49.8 \mathrm{~mm}, 52.2 \mathrm{~mm}, 62.1 \mathrm{~mm}$ and $65.4 \mathrm{~mm}$. Several of the collected oysters were also fouled by the bay barnacle $A$. improvisus. The barnacle size does not hint at 


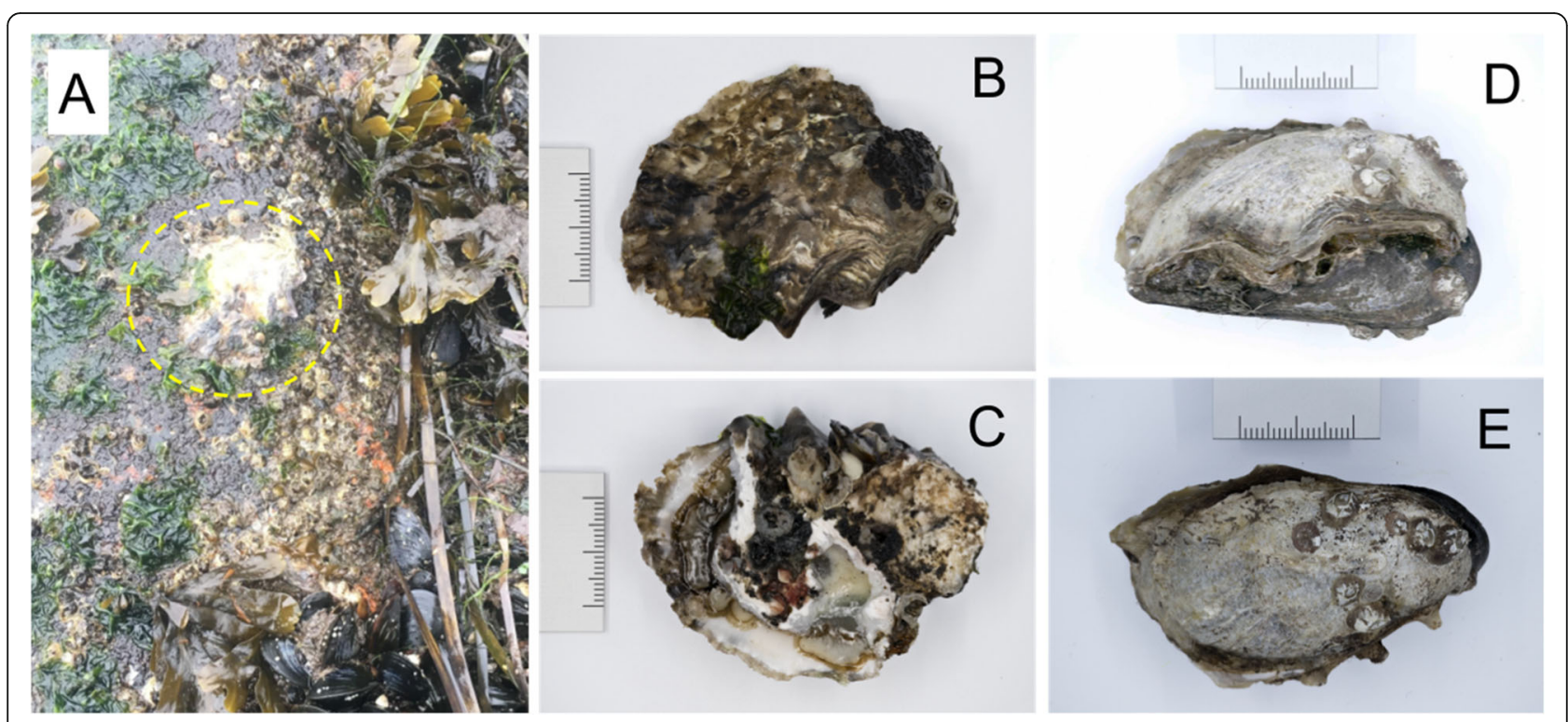

Fig. 2 Photographs of the oysters discovered in the Kiel Bight. a: In situ photograph of the first oyster discovered at the Tirpitzmole on October 12, 2019. The yellow circle highlights the location of the oyster. b, c: Photographs of the same oyster after removal on November 12, 2019. b: Right valve, c: Left valve. During removal, some shell pieces broke off, specifically those attached to the substrate, which reveal gills and somatic tissue. $\mathbf{d}$, e: Ventral and dorsal photographs of one of the oysters collected on March 3, 2020 from a quay wall in the inner Kiel Bight, attached to blue mussels. Note that blue mussel and oyster are photographed together, as the oyster has overgrown one of the mussel shells completely.

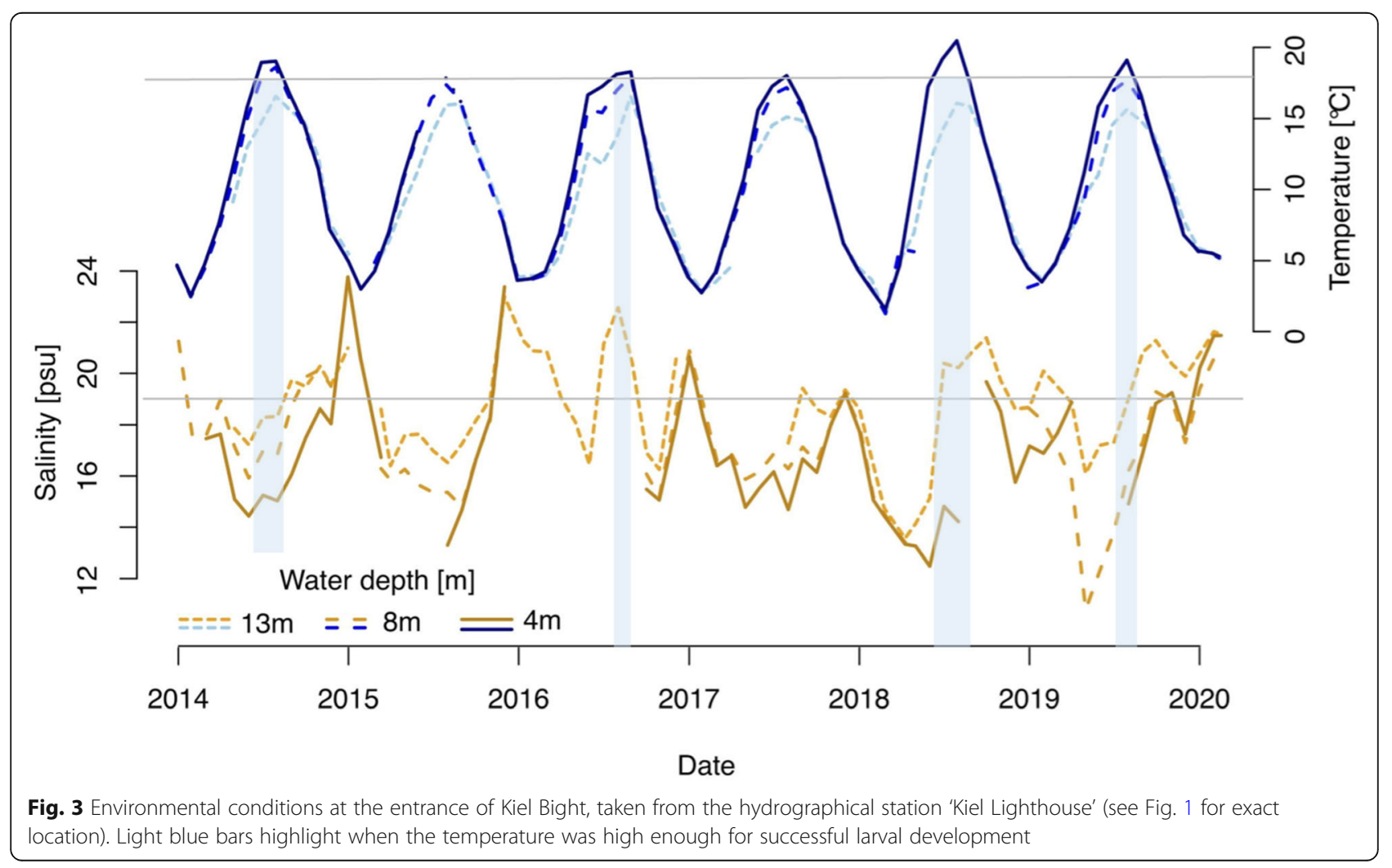


the age of the oyster because $A$. improvisus can grow up to $16 \mathrm{~mm}$ within a few months (Laihonen and Furman 1986).

\section{Environmental conditions}

The salinity during the collection events, measured with a VWR Portable Refractometer, was 25 to 26 PSU, which is unusually high for the area. Long-term salinity measurements from 2004 to 2014 from this area of the Baltic Sea ranged from 13.5 PSU in summer to 19.2 PSU in winter (Lennartz et al. 2014). To get a more detailed view of the salinity and temperature fluctuations in the past six years, we calculated monthly averages from hourly measurements taken at the hydrographic station 'Kiel Lighthouse' (Fig. 3), which were made available by BSH on March 5, 2020 (https://www.bsh.de/DE/ DATEN/Meeresumweltmessnetz/Jahreszeitreihen/jahreszeitreihen_node.html). We found unusually high salinities and temperatures during the late summer of 2018, suitable for the development of $M$. gigas larvae. In prior years, salinity peaks were even higher, but restricted to the winter months, representing the normal hydrographic pattern of high winter salinity and lower summer salinity for the western Baltic Sea (Lennartz et al. 2014).

\section{Morphological and molecular species identification}

We identified the collected oysters as Magallana gigas (Thunberg, 1793) using a dichotomous key (Hayward and Ryland 1995). To confirm our morphological identification, we sequenced the barcoding fragment of the mitochondrial cytochrome oxidase subunit one gene (COI) from three oysters using the universal primer pair LCO1490-HCO2198 (Folmer et al. 1994). The obtained sequences (GenBank acc. no. MT193618 - MT193620) were identical to each other, and to the following published sequences of Magallana gigas deposited in GenBank: XM_020066396, MN064627, KP099007, KJ855245, KJ855244, KJ855241, HQ718598, HM626169, FJ743528, FJ717608, EU007508, AY632567, and AF177226. These BLAST search results (Madden 2002) confirm therefore the morphological species identity.

\section{Discussion}

The discovery of feral oysters in the Baltic Sea proper represents a noteworthy expansion of its range; it appears to mark an expansion into brackish water that exceeds the physiological limits of $M$. gigas larvae. However, the salinity and temperature were unusually high during the late summer of 2018, suitable for the development of $M$. gigas larvae (Fig. 3). In prior years, salinity peaks were even higher, but restricted to the winter months. We thus propose that the oysters in the Kiel Bight were about 1.5 years old at time of discovery. This assumption is supported by the size of the oysters. The first oyster was discovered on October 12, 2019. At the time of discovery, it was close to $60 \mathrm{~mm}$ long. Given the typical spawning of oysters in late July followed by settlement of larvae from August to September (Reise et al. 2017; Troost 2010), the specimen seems too large to have settled in 2019, in which case it would have been only 3 months old (Diederich 2006). It seems more likely that the oysters were at least 14 and 17 months old at time of collection. They may have been older if growth is slowed in the lower salinity of the western Baltic Sea. Settlement of these oysters in an earlier year, however, seems unlikely given the unfavorable environmental conditions in the late summers of 2014-2017 (Fig. 3). We hypothesize that the occurrence of Pacific oysters in the Baltic Sea proper was possible due to significant deviations from 'normal' hydrographic and climatic conditions, coupled with an already ongoing range expansion. $M$. gigas has been established in the Kattegat area since the 2000s (Wrange et al. 2010), which is the probable source of $M$. gigas in the Kiel Bight.

When the Pacific oyster $M$. gigas was first introduced into the North Sea, it was not thought to reproduce successfully due to the low water temperature (Drinkwaard 1998). But only a few years after the establishment of oysters in aquaculture, the first wild settlement of oysters was observed, facilitated by increased water temperatures. Similarly, the current presence of $M$. gigas in the Kiel Bight was likely facilitated by the prevailing high temperatures and salinities in the western Baltic Sea during late summer, when $M$. gigas larvae develop in the plankton. If those conditions occur more frequently in the future, or if $M$. gigas adapts to lower salinities, $M$. gigas could colonize larger parts of the Baltic. Low salinities and temperatures at other times of the year are not problematic for oysters once they have settled (Diederich 2006). Future monitoring of the oysters' distribution and especially their reproductive status will show if the presence of oysters in the Baltic Sea is a rare coincidence, or if this discovery marks the first step towards selfsustaining oyster populations in the Baltic Sea.

Acknowledgements

We would like to thank Fabian Haas for photographing the oysters after collection, and two anonymous reviewers for their helpful comments.

\section{Authors' contributions}

Christine Ewers-Saucedo collected the first oyster and wrote the manuscript, Nele Heuer, Zoe Moesges and Kira Ovenbeck collected oysters, generated the $\mathrm{COI}$ sequences and edited the manuscript, Nicole Schröter collected oysters, measured barnacles and edited the manuscript, Dirk Brandis edited the manuscript. The author(s) read and approved the final manuscript.

\section{Funding}

The German BMBF grant "MARSAMM" (01UQ1711) provided funding for the salary of Christine Ewers-Saucedo, Nele Heuer and Nicole Schröter, as well as for resources needed for preserving the oysters and sequencing. Open access funding provided by Projekt DEAL. 


\section{Availability of data and materials}

The collected specimens are deposited at the Zoological Museum of the Kiel University (ZMK Mo10400-Mo10406. The generated genetic sequences were deposited in the NCBI GenBank repository under the accession numbers MT193618 - MT193620.

\section{Ethics approval}

The oysters were collected under a standing permit to collect invasive species issued by the government of the German federal state SchleswigHolstein. They were frozen or preserved in 95\% Ethanol directly after collection.

\section{Consent for publication}

Not applicable. Pictures were taken by Christine Ewers-Saucedo and at the facilities of the Zoological Museum of the Christian-Albrechts University.

\section{Competing interests}

We declare no competing interests.

Received: 8 May 2020 Accepted: 21 July 2020

Published online: 10 August 2020

\section{References}

Bock G, Lieberum C. Neobiota in ausgewählten Häfen der schleswigholsteinischen Ostsee [LLUR AZ 0608.451614]. Zwischenbericht im Auftrag des Landesamt für Landwirtschaft, Umwelt und ländliche Räume SchleswigHolstein (LLUR); 2019

Cardoso JF, Langlet D, Loff JF, et al. Spatial variability in growth and reproduction of the Pacific oyster Crassostrea gigas (Thunberg, 1793) along the west European coast. J Sea Res. 2007;57:303-15.

Diederich S. High survival and growth rates of introduced Pacific oysters may cause restrictions on habitat use by native mussels in the Wadden Sea. J Exp Mar Biol Ecol. 2006;328:211-27.

Diederich S, Nehls G, van Beusekom JEE, Reise K. Introduced Pacific oysters (Crassostrea gigas) in the northern Wadden Sea: invasion accelerated by warm summers? Helgol Mar Res. 2005;59:97-106. https://doi.org/10.1007/ s10152-004-0195-1.

Dolmer P, Holm MW, Strand A, Lindegarth S, Bodvin T, Norling P, Mortensen S. The invasive Pacific oyster, Crassostrea gigas, in Scandinavian coastal waters: a risk assessment on the impact in different habitats and climate conditions. Fisken Og Havet. 2014;2-2014:1-76.

Drinkwaard AC. Introductions and developments of oysters in the North Sea area: a review. Helgoländer Meeresuntersuchungen. 1998;52:301.

Fey F, Dankers N, Steenbergen J, Goudswaard K. Development and distribution of the non-indigenous Pacific oyster (Crassostrea gigas) in the Dutch Wadden Sea. Aquac Int. 2010;18:45-59.

Folmer O, Black M, Hoeh W, et al. DNA primers for amplification of mitochondrial cytochrome c oxidase subunit I from diverse metazoan invertebrates. Mol Mar Biol Biotechnol. 1994:3:294-9.

Hayward P, Ryland J, editors. Handbook of the marine fauna of north-West Europe. New York: Oxford University Press; 1995.

Laihonen P, Furman ER. The site of settlement indicates commensalism between blue mussel and its epibiont. Oecologia. 1986;71:38-40. https://doi.org/10. 1007/BF00377317.

Lennartz ST, Lehmann A, Herrford J, et al. Long-term trends at the time Series Station Boknis Eck (Baltic Sea), 1957-2013: does climate change counteract the decline in eutrophication? Biogeosciences (BG). 2014;11:6323-39.

Madden T. The BLAST sequence analysis tool. Chapter 16. In: McEntyre J, Ostell J, editors. The NCBI handbook. Bethesda: National Center for biotechnology information (US); 2002.

Nehring S, Reise K, Dankers N, Kristensen PS. Alien species. Wadden Sea Ecosystem. 2009;25:1-28.

Reise K. Pacific oysters invade mussel beds in the European Wadden Sea. Senckenberg Marit. 1998;28:167-75. https://doi.org/10.1007/BF03043147.

Reise K, Buschbaum C, Büttger H, Rick J, Wegner KM. Invasion trajectory of Pacific oysters in the northern Wadden Sea. Mar Biol. 2017;164:68.

Reise K, Dankers N, Essink K. Introduced species. Wadden Sea Ecosystem. 2005;19: $119-30$.

Rico-Villa B, Pouvreau S, Robert R. Influence of food density and temperature on ingestion, growth and settlement of Pacific oyster larvae, Crassostrea gigas. Aquaculture. 2009;287:395-401.
Smaal A, Kater B, Wijsman J. Introduction, establishment and expansion of the Pacific oyster Crassostrea gigas in the Oosterschelde (SW Netherlands). Helgol Mar Res. 2009;63:75.

Troost K. Causes and effects of a highly successful marine invasion: case-study of the introduced Pacific oyster Crassostrea gigas in continental NW European estuaries. J Sea Res. 2010;64:145-65. https://doi.org/10.1016/j.seares.2010.02.004.

Wolff WJ, Reise K. Oyster imports as a vector for the introduction of alien species into northern and western European coastal waters. In: Invasive aquatic species of Europe. Distribution, impacts and management. In: Springer; 2002. p. 193-205.

Wrange A-L, Valero J, Harkestad LS, et al. Massive settlements of the Pacific oyster, Crassostrea gigas, in Scandinavia. Biol Invasions. 2010;12:1145-52.

\section{Publisher's Note}

Springer Nature remains neutral with regard to jurisdictional claims in published maps and institutional affiliations.
Ready to submit your research? Choose BMC and benefit from:

- fast, convenient online submission

- thorough peer review by experienced researchers in your field

- rapid publication on acceptance

- support for research data, including large and complex data types

- gold Open Access which fosters wider collaboration and increased citations

- maximum visibility for your research: over $100 \mathrm{M}$ website views per year

At BMC, research is always in progress.

Learn more biomedcentral.com/submissions 